\title{
Når middelet vanhelliger målet - motstridende budskap i implementeringen av medarbeiderdrevet innovasjon i offentlig sektor
}

\author{
Av Kristiane Marie Fjoer Lindland *)
}

\begin{abstract}
Resymé
Offentlig sektor må innovere, og da medarbeiderne er sentrale for kommunenes innovasjonsevne, ønsker mange kommuner å fostre medarbeiderdrevet innovasjon (MDI). Dette til tross for at vilkårene for MDI bryter radikalt med offentlig sektors arbeidsformer. Funn fra kommuner indikerer, at fordi MDI implementeres som et konsept, blir det lettere å implementere. Samtidig kan implementeringsmåten heller hemme enn fremme MDI. Gjennom å forstå «innovasjonskonsepter på reise» som et signifikant symbol (Mead, 1934), diskuterer jeg hvordan implementeringsprosessen i to kommuner førte til paradoksale forståelser av MDI. Funnene og diskusjonen bidrar til å forstå hvorfor implementeringen av ulike organisasjonsideer ofte ikke fører til reell endring over tid.
\end{abstract}

\section{A. Introduksjon}

Norske kommuner vil i nær fremtid måtte håndtere økte brukerbehov, samtidig som at de offentlige ressursene vil reduseres (NOU, 2016,3). Som en konsekvens av dette leter kommunene etter organisasjonskonsepter, som kan bidra til innovasjon (Holmen og Ringholm, 2019, Nielsen et. al, 2019). Ifølge Hjelmar (2019) og Gieske et al. (2019) handler ikke innovasjon i offentlig sektor om unike, nye ideer, som blir satt ut i livet, men heller om eksisterende ideer som blir tatt i bruk i nye

*) Kristiane Marie Fjær Lindland (PhD) er førsteamanuensis ved Universitetet i Stavanger 
kontekster. Innovasjonskonsepter utviklet i privat sektor kan ikke uten videre overføres til offentlig sektor, da konseptene ofte står i kontrast til offentlig sektors kontekst og logikk (Nielsen et al, 2019), og må oversettes (Czarniawska og Joerges, 1996, Czarniawska og Sevón, 1996, Røvik, 2007) til en offentlig kontekst (Nielsen et al, 2019). Med andre ord; innovasjon i offentlig sektor handler i hovedsak om å hente ideer utenfra for så å tilpasse disse til den en kontekstualisert og legitim prosess for, hvordan innovasjon drives frem i offentlig sektor.

Innovasjon i offentlig sektor skal være strategisk og bidra til kontinuerlig endring (Hjelmar, 2019). Samtidig må innovasjon i offentlig sektor være en institusjonalisert aktivitet, der den innovative idé blir realisert gjennom programmet den struktureres gjennom. Programmet (prosessen) strukturerer arbeidsmåtene, hvem som er involvert, og hva aktivitetene kan være (ibid). Programmene må være i tråd med det som ses som legitime normer for endring i offentlig sektor, og blir ikke endret ved, med mindre de ikke viser seg å fungere over tid. New Public Management og byråkratier blir forstått som hemmende for innovasjon (Torfing, 2016). Når det offentlige allikevel klarer å utvikle fungerende innovasjonskonsepter, er det fordi kjerneideene er tilpasset programmene, som igjen er i tråd med normene for en offentlig og kulturell kontekst. Nielsen et al (2019) viser at ideer fra privat sektor ofte blir «oversatt» i to omganger: først så skjer det en modifisering av ideen over til offentlig sektor. I neste omgang tilpasses den inn i den enkelte organisasjon. Hjelmar (2019, s 14) etterlyser mer forskning på hvordan denne institusjonaliseringsprosessen fungerer i ulike situasjoner, og hvordan innovasjonen er påvirket av implementeringsprosessen. Denne artikkelen er en respons på denne oppfordringen.

MDI kan i offentlig sektors kontekst forstås som en forholdsvis radikal innovasjonsform, der medarbeidere initierer og driver frem nye løsninger på behov de selv identifiserer. Denne innovasjonsformen impliserer at medarbeidere har en stor grad av handlingsrom i selv å vurdere behovet for alternative løsninger, tilgjengelige ressurser og mandat til å initiere og gjennomføre endringer. MDI bryter dermed med New Public Managements (NPMs) fokus på prosedyrer, optimalisering og kontroll. Men hva skjer når kjerneideen står i kontrast til organisasjonen den skal implementeres inn i? Utforskningen av dette spørsmålet tar utgangspunkt i en studie av implementeringen av MDI-konseptet i to norske kommuner. Forskningsprosjektet skulle følge kommunenes arbeid med å fostre en kultur for MDI. Funnene fra studien viser at mange av de grepene som ble tatt for å implementere MDI, faktisk kunne virke kontra-produktivt på målet om å fostre MDI. Spørsmålet jeg stiller er:

Hvordan kan prosessen som legitimerer implementeringen av MDI-konseptet i norske kommuner, samtidig bidra til å hemme fostringen av en kultur for MDI? 
Funnene diskuteres ut fra en forståelse av MDI og implementeringsprosessene som signifikante symboler (Mead, 1934), som får sin mening gjennom samhandling. Forankret i Pragmatismen utforsker jeg hvordan fortolkningen av MDI som et «organisasjonskonsept på reise» kan bidra til å forstå hvordan MDI som konsept kan vellykket implementeres, samtidig som grunn-ideen i MDI svekkes. Dette er ikke en drøfting av hvilke former for MDI som fører til paradoksale forståelser. Det er heller en drøfting av hvordan et konsept og dets implementeringsprosess kan stå i kontrast til hverandre, der internalisering av sosiale forventinger regulerer hva som er mulig å gjøre.

Artikkelen er strukturert som følger: først gir jeg en kort oversikt over hvordan MDI knytter seg til en nordisk arbeidslivskontekst, og hvilke faktorer som har vist seg å fremme MDI. Så skisserer jeg det teoretiske rammeverket for meningsutvikling og identitetsutvikling som jeg bygger artikkelen på, før jeg gir en kort beskrivelse av metodologien og metodene og studien som empirien er hentet fra. Deretter presenterer jeg funnene fra studien, knyttet til hvordan MDI ble implementert, og hvordan dette korresponderer med faktorene som fremmer MDI. Så diskuterer jeg hvordan implementeringsprosessen som meningsskapende prosess, kan komme til å motvirke kjerneideen for MDI, før konkluderende bemerkninger og forslag til videre forskning gis. Dette kan bidra til å forstå implementeringsprosesser som noe mer enn kun et legitimerende verktøy for å «selge inn» et nytt konsept. Prosessene er også meningsskapende prosesser som bidrar til å definere hvem deltakerne blir i relasjon til hverandre, og dermed hvilket handlingsrom de kan ha i realiseringen av det nye konseptet. Jeg starter nå først med å beskrive MDI som kjerneidé, og hvilke faktorer som fremmer MDI.

\section{B. Hvordan fostres medarbeiderdrevet innovasjon?}

Medarbeiderdrevet innovasjon har de senere årene blitt forstått som et innovasjonskonsept som kan passe godt for offentlig sektor. Kanskje ikke så rart, da medarbeiderne ifølge det norske innovasjonsbarometeret bli fremhevet som en av de viktigste faktorene for å fremme innovasjon i offentlig sektor (https://www.ks.no/i). Smith et al (2008, s.1) definerer MDI som «genereringen og implementeringen av ideer, produkter og prosesser skapt av en enkelt ansatt, eller gjennom felles innsats fra to eller flere ansatte» (min oversettelse). Innovasjon blir generelt fremhevet som noe positivt (Osborne og Brown, 2013, Holmen og Ringholm, 2019, Torfing, 2016), og medarbeiderdrevet innovasjon har nok en enda mer positiv klang, da det anerkjenner medarbeidernes betydning i å utvikle bedre løsninger for brukerne. Det forventes også å bidra til mer effektive løsninger, høyere kvalitet og bedre medarbeidertrivsel (Hjelmar, 2019). MDI har også blitt koblet til den nordiske arbeidslivsmodellen, med korte maktavstander og høy grad av medarbeidermedvirkning (Hansen, et al 2017, Hjelmar, 2019). Denne arbeidslivsmodellen harmonerer med de faktorene som blir forstått som å fremme MDI. 
Kesting og Ulhøi (2010, s.76-79) identifiserer fem aspekter som fremmer MDI: 1) Høy grad av lederstøtte; 2) Høy grad av intra-organisatorisk støtte i form av ressursallokering (slakk); 3) Нøy grad av medarbeider-autonomi; 4) Belønning av kollektive aktiviteter; og endelig: 5) Korte maktdistanser og lite lovreguleringer mellom medarbeidere (medarbeiderrepresentanter) og ledere. Likeledes fant Smith et al (2008) og Hansen et al (2017), at lederstøtte, autonomi, samarbeid og en kultur for innovasjon fostrer MDI, hvilket er i tråd med det også Kesting og Ulhøi (2010) fant. Sammenfallende med dette fant Aasen et al (2012), at ledere må utøve ledelse på en annerledes måte enn den mer tradisjonelle toppstyrte lederstilen, som vi finner typisk finner i organisasjonsbyråkratier.

MDI fordrer altså andre rolleforståelser av ledere og medarbeidere til hverandre, sammenliknet med til de profesjonelle identitetene som er vanlig i offentlig sektor. Sentralt i offentlige organisasjoner står kravet om ansvarlighet, og ansvarligheten er forankret i at lovverk, reguleringer og prosedyrer følges (Torfing, 2016). Ansvaret følger ledelseslinjene i en byråkratisk organisasjon der bestemmelser, initiativer og endringer kommer ovenfra, fra lokalt eller nasjonalt politisk hold eller fra nasjonale eller internasjonale myndigheter. Om innovasjonsprosesser skal initieres og drives frem av medarbeidere i sine lokale arbeidssituasjoner, krever det at medarbeidere og ledere endrer sin samhandling og forståelse av hva som forventes av dem. Medarbeidere må da ta ansvaret for å identifisere utfordringene, mobilisere kolleger til å bidra til å finne løsninger og å drive frem løsningene. Ledernes rolle blir å oppmuntre til og tilrettelegge for slike medarbeiderroller, allokere nødvendige ressurser og legitimere initiativene overfor omgivelsene.

A tilrettelegge for MDI i offentlig sektor vil dermed bety å styrke de faktorene, som fremmer MDI. En naturlig konsekvens av dette vil være nye måter å jobbe på, som også vil innebære re-defineringer av hva det vil si å være en god medarbeider og en god leder. Helt konkret blir det empiriske spørsmålet om måten MDI ble implementert på i to kommuner faktisk bidro til å fremme de faktorer som har blitt påpekt som fostrende på MDI. Før jeg presenterer funnene relatert til spørsmålet, vil jeg skissere opp det teoretiske rammeverket for å forstå implementeringsprosessen som en meningsutviklende prosess, der forståelsen av hva MDI kan være i den enkelte organisasjon, relasjon og situasjon, defineres.

\section{Meningsutvikling som en sosial og kontinuerlig prosess}

I translasjonslitteraturen blir organisasjoners implementering av nye organisasjonskonsepter ofte behandlet som oppskrift som blir kopiert, adaptert eller transformert fra en organisasjon inn i en ny organisasjon (Røvik, 2007). Innovasjonskonsepter, som en form for organisasjonskonsepter, kan også forstås som kommunikative, sosiale objekter som kontinuerlig re-produseres og re-fortolkes 
gjennom samhandling. Forståelsen av et konsept som en kontinuerlig meningsutviklende prosess, heller enn en entitet, vil stille spørsmål ved om et konsept kan overføres, kopieres eller transformeres, som om det var en «ting» (Lorino, 2018, Crevani og Endrissat, 2016).

I denne artikkelen forstås meningsutvikling som det Mead (1934) kalte den sosiale prosess (the social act) av gest-respons, der en gest (et utsagn, en handling, eller en hendelse) fremkaller en respons i den andre, som igjen blir gesten, den ene responderer på. Kommunikative situasjoner av gest-respons har to aspekter ved seg. Det definerer ikke bare meningen i en situasjon, men også hvem vi blir i situasjonen (Mead, 1934, Wadel, 1999). Til ethvert saksbudskap følger det dermed også et relasjonelt budskap, og disse budskapene bidrar til å forme vår forståelse av situasjonen, og hva som forventes av oss i situasjonen. Og hvem vi forstår oss selv å bli i relasjon til andre i situasjonen, bidrar igjen til våre forventinger om hva som blir mulig eller ønskelig å gjøre videre. Med andre ord; meningen som utvikles i en situasjon, definerer hva vi forstår som mulighetene i for videre handlinger.

Gjennom å sosialiseres inn i nye grupper, utvikler vi mer eller mindre felles forståelser for verden, og hvilke forventinger vi har til egne og andres handlinger i ulike situasjoner. Slike felles forventinger bidrar til forutsigbarhet i samhandlingen og rutinemessige responser på ulike gester. Dette bidrar også til at vi kan samhandle meningsfullt også med fremmede som er sosialisert inn i de samme gruppene som oss selv. Mead (1934) beskrev felles forståelser for ulike situasjoner og fenomener for Signifikante symboler. En busstur er et eksempel på et signifikant symbol vi deler med andre bussreisende. Gjennom å være sosialisert inn i aktiviteten «reise med buss», har vi relevante forventinger om hvordan bussreisen vil forløpe. Vi vet hvordan vi skaffer gyldig billett, hvordan vi signaliserer at vi vil gå av, og de uskrevne reglene for kommunikasjon med andre passasjerer. Dette hjelper oss å opptre i tråd med egne og andres forventinger.

Om vi velger å forstå «organisasjonskonsepter på reise» som et signifikant symbol, som fremkaller samme stimulus til respons i en selv som i andre, betyr det at deltakere i organisasjoner har felles utviklede forståelser av hva slike konsepter på reise innebærer. Et organisasjonskonsept som er nytt for en organisasjon, utvikler mening gjennom samhandling omkring konseptet. Konseptet blir en gest for berørte ledere og medarbeidere å respondere på. Meningen ulike aktiviteter, hendelser og utsagn får, bidrar til å definere forståelsen av situasjonen, og hvem deltakerne forstår seg selv som i situasjonen. Dette innebærer samtidig at meningen av det signifikante symbolet kontinuerlig utvikles, justeres og re-fortolkes gjennom samhandlingen. Meningsutviklingen veiledes av utallige andre signifikante symboler, som bidrar til å definere situasjonen og dermed også gyldigheten av ulike signifikante symboler i situasjonen. 
Forståelsen av et konsept som en kontinuerlig meningsutviklende prosess har implikasjoner for, hvordan vi forstår definisjonsmakten i implementeringen av organisasjonskonsepter. Denne forståelsen impliserer at ledelsen ikke kan definere forståelsen av MDI i en organisasjon alene, men at konseptet får sin mening gjennom samhandlingen i implementeringen (Griffin og Stacey, 2005). Ledelsen har gjennom sin posisjon allikevel mer definisjonsmakt i meningsutviklingen av konseptet enn medarbeidere har, da de legger føringene for implementeringsprosessen (ibid). Hvis ledelsen i en organisasjon ønsker å fostre MDI, må man altså samhandle på måter som fremmer og styrker medarbeidernes autonomi, reduserer maktavstand, øker tillit, tilføre nødvendige ressurser og bidrar til en kultur for prøving og feiling. Implementeringsprosessen bidrar i seg selv til å indikere hva som forventes av ledere og medarbeidere, og dermed hvilke sosiale identiteter de får i relasjon til hverandre.

I presentasjonen av funnene fra studien av to kommuner som implementerte MDI, vil jeg vise hvordan implementeringen av MDI førte til en meningsutvikling som i stor grad motstred kjernebudskapet til MDI. Før jeg presenterer funnene, vil jeg kort presentere studien som funnene er hentet fra, og hvordan analysen er utført.

\section{Metodologi og metode}

Denne artikkelen er basert på en longitudinell studie (2015-2017), der vi studerte hvordan MDI ble implementert som en organisasjonsoppskrift for kommunal innovasjon i fire norske kommuner. Studien ble ledet av IRIS (International Research Institute of Stavanger) og gjennomført i samarbeid med NORUT (Northern Research Institute). To av kommunene lå I Nord-Norge, de to andre kommunene lå i sør-vest. Det er de to sistnevnte jeg har basert denne artikkelen på. Hele kommuneorganisasjonene var omfattet av MDI-satsingen, og det var den administrative ledelsen i de to respektive kommunene, som initierte og drev frem prosessen.

Det ble i studien totalt gjennomført 113 intervjuer, hvorav ca. 60 i de to kommunene adressert i denne artikkelen, der noen av disse var gruppeintervjuer. I tillegg deltok vi på innovasjonsdager og enkelte andre aktiviteter relatert til implementeringen av MDI. Informantene var kommunepolitikere, kommunale ledere og mellomledere og medarbeidere som var involvert i konkrete innovasjonsprosjekter i regi av MDI-satsingen. Vi gjennomførte også to surveys, men de er ikke brukt som materiale i denne artikkelen.

Forankret i eksisterende forskning på MDI, utviklet vi intervjuguider der vi adresserte elementer som er funnet å kunne bidra til å fremme MDI. Vi la vekt på hva ledelsen brukte av virkemidler for å fremme MDI, og hvordan disse virkemidlene bidro til å fremme en kultur og arbeidsmåter for MDI. 
Funnene vi gjorde underveis, bidro til å informere oss om, hva som var de sentrale temaene, og dermed også hvordan vi også måtte justere temaene vi var interessert i.

Temaet for denne artikkelen har utviklet seg abduktivt. Intensjonen med studien var å følge kommunenes arbeid med å utvikle en kultur for MDI. Gjennom studien har det vokst frem en erkjennelse av at måten MDI ble implementert på, har ført til konflikterende forståelser av hva MDI kunne være i de to kommunene.

Jeg har vært interessert i hvordan implementeringen av MDI får mening i det daglige arbeidet i kommunene, og hvordan meningsutviklingen underveis gir retning og legitimering for de handlinger som gjøres. Når jeg har analysert det empiriske materialet for denne artikkelen, har jeg kodet intervjuene og observasjonene ut fra hemmende og fremmende faktorer for MDI. Materialet har så blitt kategorisert ut fra konflikterende forståelser som ble uttrykt, og min fortolkning av hva de konflikterende forståelsene handlet om.

Fortolkningene av utsagn og hendelser er mine, basert på informantenes uttalte fortolkninger. Informantene har delt situasjoner og forståelser med oss som har begrunnet deres oppfatning av hvordan MDI-satsingen har blitt implementert i de to kommuneorganisasjonene. Vårt utvalg av informanter hadde også en svakhet ved at vi fokuserte på dem, som var sterkt involvert i satsingen, og kjenner kun til de «u-involverte» gjennom de involvertes utsagn.

Det vil være flere fortolkninger av hvordan implementeringsprosessen bidro til å utvikle forståelsen av hva MDI kunne være i de to kommunene. Mine fortolkninger er det Martela (2011) kaller plausible fortolkninger, som får sin troverdighet gjennom at vi fulgte kommunene og aktivitetene over tre år, og ved at vi har flere informanter som fremhever og fortolker de samme situasjonene.

\section{E. Motstridende forståelser i implementeringen av MDI i to kommuner}

Medarbeiderdrevet innovasjon (MDI) utvikles i arbeidsfellesskap der medarbeidere prøver å løse utfordringer de står ovenfor i arbeidssituasjonen (Kesting og Ulhøi, 2010). Jeg vil nå vise hvordan implementeringen av MDI som et organisasjonskonsept i to norske kommuner bidro til konflikterende budskap om hva MDI kunne bety for ledere og medarbeidere i deres daglige arbeid. Funnene indikerer fire hovedmotsetninger: 1) manglende samsvar mellom kjerneidé og handlinger; 2) et nedenfra-og-opp-konsept, som blir implementert ovenfra-og-ned; 3) motsetningen mellom MDI som prosjekt og MDI som en del av daglig arbeidspraksis, og tilslutt; 4) motsetningen mellom MDI som mulighet og MDI som krav. 


\section{Manglende samsvar mellom kjerneidé og handlinger}

Da MDI ble presentert som satsingsområde i de to kommunene, ble medarbeiderne fremholdt som de viktigste for å skape bedre tjenester og løsninger i tjenesteområdene. Medarbeiderne ble oppfordret til å ta initiativ med utgangspunkt i egen virksomhet og arbeidssituasjon og utvikle bedre løsninger. Kommuneledelsen i de to kommunene definerte tydelig hva MDI skulle være i deres kommune. I den ene kommunen handlet det i stor grad om å forenkle, forbedre og fornye eksisterende løsninger. I den andre kommunen ønsket ledelsen, at løsningene også kunne være mer radikale. Kommunene brukte de samme konsulentene for å støtte implementeringen, og BLT (Behovløsning-testing) ble brukt som felles metodikk.

På tross av at budskapet om MDI løftet frem kommunenes medarbeidere som de sentrale for å lykkes med å realisere MDI, ble inspirasjonen til MDI-satsingen ikke hentet fra egne kommunale virksomheter, men hentet inn som et innovasjonskonsept fra foregangskommune Vestre Toten og Århus i Danmark. For å vekke entusiasme ble i begynnelsen innovasjonsprosjekter fra andre kommuner presentert som eksempler på hva som kunne skapes gjennom å fostre MDI. Ledelsen søkte dermed ikke blant egne medarbeidere og aktiviteter etter eksempler på MDI. Selv om det eksplisitte budskapet handlet om at medarbeiderne var dem som skulle drive frem innovasjonsarbeidet, støttet av lederne, snakket kanskje lederne mer om medarbeiderne og til medarbeiderne enn med medarbeiderne i etableringen av MDI satsingen. Dermed ble det implisitte budskapet at potensiale for MDI ikke fantes blant medarbeiderne i utgangspunktet, men noe som kunne læres utenfra.

\section{Ovenfra-og-ned heller enn nedenfra-og-opp}

Implementeringen av MDI-konseptet i organisasjonen ble ledet av ledergruppene - støttet av innleide konsulenter - gjennom strukturerte aktiviteter. Implementeringen bygde på tre pilarer: opplæring i metoder (BLT og etter hvert også Lean), innovasjonsprosjekter og en sentralt plassert støtteinfrastruktur i form av henholdsvis en ressursgruppe og en innovasjonsgruppe.

I begynnelsen av implementeringsarbeidet var hovedfokuset på å forankre MDI-satsingen i ledergruppene, for så å fokusere mer på mellomlederne. Ledere og mellomledere ble kurset og involvert i å lære konseptet og arbeidsmetoder. Begrunnelsen for denne var at det var spesielt mellomlederne som måtte drive frem initiativet i medarbeiderne og at de var det viktige bindeleddet og kommunikasjonskanal fra ledelsen til medarbeiderne. Noen medarbeidere ble involvert i metodeopplæringen gjennom innovasjonsprosjekter som ble satt i gang, men disse prosjektene ble også valgt ut av lederne.

Spredningen av MDI-satsingen gikk senere enn ledelsen hadde forventet. For å øke spredningen ble det derfor etter hvert økt press på å gjennomføre aktiviteter, så som at "alle” virksomheter skulle 
ha hatt innovasjonsprosjekt og ha brukt støttetjenestene, og alle ledere og mellomledere skulle ha deltatt i opplæring på MDI. I den ene kommunen ble alle virksomheter pålagt å utvikle en egen innovasjonsplan. I den andre kommunen ble det en klar forventing om at de ulike enhetene aktivt benyttet støtte-tjenestene i form av metodeopplæring og fasilitering av prosesser. Slik kunne MDIsatsingene også vise aktivitet og resultater av satsingene gjennom dokumentasjon av gjennomførte aktiviteter.

For medarbeiderne førte måten MDI ble implementert på, at de hadde lite autonomi til selv å vurdere hvilke ideer som burde prioriteres. Selv om det eksplisitte budskapet satte medarbeiderne i sentrum, viste fokuset på ledere og mellomledere at det var dem som skulle initiere og realisere MDI-arbeidet. Dermed ble den eksisterende rolleforståelsen av lederne som de aktive initiativtakerne og kontrollører og medarbeiderne som følgere og kontrollerte, opprettholdt.

\section{Skille mellom prosjekt og praksis}

Kravene som ble stilt til deltakelse i MDI-aktivitetene og hvordan dette skulle gjøres ved bruk av bestemte metoder, bidro antakelig til å definere MDI-satsingen som et ovenfra styrt prosjekt, som ledere og medarbeidere pliktet å delta i. Selv om det eksplisitte budskapet knyttet MDI til medarbeidernes egne arbeidsoppgaver, deres kontekstuelle forståelse og brukernes behov, så var MDI-aktivitetene ofte ikke koblet til noe medarbeiderne opplevde som et reelt behov. En informant uttrykte dette slik:

"Ressursgruppa har vært viktig, men det har vært for lite fokus på behovet der ute. Det blir brukt altfor mye tid på å lage ting, som ingen der ute har tatt i bruk."

I den andre kommunen kom dette til uttrykk i relasjon til innovasjonsplanene. Når ledelsen ønsket at alle virksomhetene skulle lage sin egen innovasjonsplan, opplevde de at innovasjonsplanene var fra-koblet virksomhetenes aktiviteter. Dette indikerer at medarbeiderne ikke forsto innovasjonsplanen som basert på egne arbeidsoppgaver og praksiser. Innovasjonsplanen var noe medarbeiderne var pålagt å gjøre, uten at det gav særlig mening for dem. For mellomlederne og virksomhetslederne ble oppgaven med å få skrevet innovasjonsplanene en vanskelig oppgave.

En tredje måte skillet mellom prosjekt og praksis kom til uttrykk på, var hvordan mange medarbeidere ute i virksomhetene hadde lite kjennskap til MDI-satsingen. Enkelte som var kritiske til nye konsepter og initiativer, valgte å vente og se hva som skjedde før de investerte tid i det. Fortolkningen av MDI-satsingen som et av mange konsepter på reise, førte til at satsingen nok ble sett på som en midlertidig satsing og ikke noe som ville endre organisasjonskulturen eller arbeidsmåtene deres. Implementeringsstrategien bekreftet langt på vei MDI et forbigående prosjekt og ikke som en gjennomgripende ny måte å jobbe på. 
Medarbeidere og virksomheter som hadde hatt innovasjonsprosjekter, var derimot utålmodige etter å ta arbeidet videre fra prosjekt til endrede arbeidsmåter. For dem var metodikken og prosessene også trening i nye måter å jobbe på. Det ble dermed et visst gap mellom dem som aktivt tok del i satsingen, og dem som kun hørte om den.

\section{MDI som mulighet og MDI som krav}

Som tidligere påpekt, har kjernebudskapet i MDI en positiv grunntone der medarbeiderne er forstått som en viktig kilde til og ressurs for innovasjon (www.ks.no). Et slikt budskap er i tråd med den Nordiske arbeidslivsmodellen er medbestemmelse og medarbeiderinvolvering er sentralt. Dette budskapet var også tydelig uttalt i kommunene gjennom ulike aktiviteter og lederpresentasjoner. For de medarbeiderne og mellomledere som allerede jobbet med MDI, om enn uformelt, bød MDIsatsingen på muligheter for å utfordre eksisterende måter å løse oppgavene på og prøve ut nye løsninger. Ikke bare kunne de få ressurser gjennom metodeopplæring og prosjektallokering; aktivitetene ble også legitimert og ble vist frem.

For andre opplevdes nok satsingen mer som ekstra krav. Kravene kom eksplisitt gjennom krav til deltakelse i og registrering av aktiviteter knyttet til MDI-satsingen. De mer implisitte kravene var knyttet til forventingen om at de skulle identifisere konkrete behov for nye løsninger. Disse løsningene skulle de så utvikle. Selv om de fleste arbeidsområder og arbeidsfellesskap har utfordringer de må løse, så var det ikke nødvendigvis enkelt å finne «passende» utfordringer for MDI-satsingen. Mange arbeidsområder hadde også en så stram tidsplan knyttet til rutiner og tjenesteleveranser, at det var lite slakk i arbeidsdagen og lite rådighet over tiden. Noen sektorer uttrykte også at det var vanskelig å utvikle nye løsninger, fordi de var i stor grad regulert av statlige krav, instrukser og planer. Dermed ble MDI-satsingen for en del av medarbeiderne krav som bidro til å øke arbeidsbelastningen, og dermed redusere eventuelt slakk og autonomi i hva som skulle prioriteres i en hektisk hverdag. Det var altså både strukturelle, organisatoriske og fag-spesifikke aspekter, som kunne gjøre det vanskelig for medarbeiderne å leve opp til de forventingene ledelsen hadde til deltakelse i MDI-satsingen.

Jeg har nå påpekt hvordan måten MDI blir implementert på i kommuner også kan bidra til å hemme de faktorene som er vist å fremme MDI; så som: autonomi, slakk i form av tid, en kultur for prøving og feiling, ressurstilgang og korte maktdistanser. I neste del vil jeg diskutere hvordan meningen MDI får i kommunene, utvikles gjennom implementeringsprosesser der flere kjente forståelser bidrar til å fortolke MDI-satsingen ganske annerledes enn MDIs kjerneidé. 


\section{F. Diskusjon}

Spørsmålet jeg stiller i denne artikkelen er:

Hvordan kan prosessen som legitimerer implementeringen av MDI-konseptet i norske kommuner, samtidig bidra til å hemme MDI?

Gjennom samhandlingssituasjoner i implementeringsprosessen blir disse initielle forståelsene av MDI re-fortolket og re-produsert. Funnene fra studien vi gjorde, viste at MDI ble implementert etter samme mønster som andre organisasjonskonsepter i offentlig sektor. Samtidig var det eksplisitte kjernebudskapet en radikal oppfordring til innovasjon nedenfra-og-opp. Slik sto det eksplisitte kjernebudskapet i kontrast til måten MDI ble forstått og håndtert gjennom implementeringen. I denne konflikterende forståelsen fikk implementeringen definisjonsmakt, og dermed ble den utviklede forståelsen av MDI kraftig modifisert.

Ut fra et Pragmatisk perspektiv kan implementeringen forstås som en meningsutviklingsprosess der MDI får sin mening gjennom samhandling. Jeg vil nå diskutere hvordan implementeringen i stor grad uttrykker et relasjonelt budskap som motstrider saksbudskapet. Så diskuterer jeg hvordan MDI blir fortolket gjennom å kobles til kjente signifikante symboler, og hvordan disse signifikante symbolene også bidrar til sosial kontroll i relasjon til aktører utenfor kommune-organisasjonene. Deretter knytter jeg disse diskusjonene til translasjonslitteraturen og spørsmålet om måten MDI blir implementert på i norske kommuner, faktisk kan bidra til å hemme implementeringen av MDI.

\section{Motstridende kommunikasjon mellom saksbudskap og relasjonelt budskap}

MDI som begrep blir eksplisitt definert og operasjonalisert i begge kommunene som beskrives i denne artikkelen. Konsekvensen av det eksplisitte budskapet vil si at om nye løsninger skal utvikles og gjennomføres basert på medarbeideres initiativ og forståelser, innebærer det en medarbeiderrolle som kan ta autonome avgjørelser basert på egne og kollegers vurderinger. Lederrollen må endres til en mer støttende og ressursallokerende rolle, der det å vise interesse og tillit er viktigere enn å styre og kontrollere prosessene. Men selve implementeringsstrategien bidrar i seg selv også til å definere hvordan MDI skal forstås. Gjennom aktivitetene som skal bidra til at MDI blir implementert, gis ikke initiativet fullt ut til medarbeiderne. Medarbeiderne kommer også frem med autonome initiativer, men disse blir ikke anerkjent som del av MDI-arbeidet. Gjennom ledelsens responser på medarbeideres autonome initiativer, viser mange ledere at MDI ikke innebærer en re-fortolkning av ledere og medarbeideres rolleforståelse. Slik bidrar implementeringen til å bevare eksisterende forståelser til hva lederes og medarbeideres handlingsrom kan være. 


\section{Meningskonstruksjon gjennom signifikante symboler}

Når et nytt begrep blir introdusert i en organisasjon, vil organisasjonens medlemmer søke etter indikasjoner på hvordan begrepet skal forstås. Relevante signifikante symboler bidrar til at involverte deltakere relativt raskt forstår hvordan de skal kategorisere begrepet.

Begge kommunene velger å implementere MDI i tråd med slik de fleste organisasjonskonsepter blir implementert i offentlig sektor: gjennom å implementere et konsept allerede justert til kommunal sektor som felt, og deretter justert til den enkelte organisasjon (Nielsen et al, 2019). Implementeringsprosessen signaliserer at MDI-satsingen er et satsingsprosjekt på lik linje med andre organisasjonsutviklingsprosjekter kommunene har hatt. Dette skaper forutsigbarhet for både ledere og medarbeidere.

Når kommunene blir introdusert for MDI, er begrepet allerede definert som et konsept som er tilpasset «feltet» offentlig sektor. Selv om MDI som tankegang og praksis kan være ny for mange i offentlig sektor, er forståelsen av organisasjonskonsepter og hvordan de implementeres i offentlig sektor, velkjent. Hvilken mening MDI får som signifikant symbol, blir i begynnelsen sterkt påvirket av at det blir implementert på samme måte som andre organisasjonskonsepter, gjennom en toppstyrt prosess, som skal «sildre ned og ut» i organisasjonen.

Det er måten det implementeres på, som gjør konseptet legitimt og forståelig i den offentlige konteksten (Hjelmar, 2019). Behovet for legitimering av konseptet er ikke kun viktig innen organisasjonen. Kommunenes ledere og medarbeidere forholder seg til en rekke signifikante symboler, som både veileder og utøver sosial kontroll i forståelsen av hva de kan og bør gjøre. Forståelsen av hva det vil si å utøve ansvarlighet i offentlig sektor, bidrar til behovet for å dokumentere prosesser, ressursallokering og resultater. Forståelsen av hva en moderne foregangskommune er, bidrar til å definere hvilke organisasjonskonsepter kommuner bør implementere, hvilke kommuner de bør se til, og hvordan de bør gå frem for å re-definere seg som en foregangskommune. Kommuneledelsen forholder seg til utallige signifikante symboler, som definerer hvilket handlingsrom de har. Skal kommunene bli forstått som attraktive kommuner å bo og jobbe i, må de agere i tråd med omforente normer for hva en moderne kommune bør og kan gjøre.

\section{Spredningen av organisasjonsoppskrifter som en fortolkende prosess}

En måte å forstå spredningen av organisasjonskonsepter på, er å forstå det som spredning av virus som virksomheter blir smittet av (Røvik, 2007). I denne artikkelen har jeg tatt en annen tilnærming til denne tematikken ved å fortolke spredningen av organisasjonsoppskrifter som en sosial prosess, som veiledes av utallige signifikante symboler som ledere og medarbeidere har internalisert. Når implementeringen av MDI i kommuner motstrider kjerneideen i MDI, så kan det være fordi 
kjerneideen bryter med de legitime forståelsene av hvordan lederskap og medarbeiderskap utøves i offentlig sektor. Derimot er en kontinuerlig leting etter nye innovasjonskonsepter en del av hva det vil si å være innovative kommuner. «Oversetterne» av organisasjonskonsepter bidrar til å utvikle implementeringsstrategier som er i tråd med gjeldende signifikante symboler. Slik kan organisasjoner legitimt implementere ideer som kanskje initielt bryter med offentlig virksomhet. Risikoen er derimot høy for at kjerneideen blir modifisert radikalt og dermed mister sin substans.

\section{G. Konklusjon}

Denne artikkelen adresserer temaet om hvordan innovasjonskonsepter som en type organisasjonskonsepter blir spredd i offentlig sektor. Til dette temaet har jeg tatt en annen tilnærming enn det lange mer kjente translasjonsperspektivet (Czarniawska og Joerges. 1996, Røvik, 2007), ved å forstå implementeringen som en sosial prosess. A forstå implementeringen av organisasjonskonsepter som en sosial prosess, innebærer å forstå handlingsrom og legitime fortolkninger som forankret i felles utviklede normer for hva ledere og medarbeidere kan være og gjøre. Hvilke normer, som gjør seg gjeldende, avhenger av hvilke signifikante symboler konseptet blir assosiert med, og her spiller implementeringsprosessen inn som et viktig signifikant symbol. Gjennom måten MDI blir introdusert på, gir ledelsen signaler til organisasjonene om hva MDI kan være i kommunene.

Denne artikkelen tar for seg et avgrenset tema, der jeg ser kritisk på hvordan kommuner implementerer MDI som konsept, og hvordan det eventuelt bidrar til å hemme mulighetene for MDI. Dette utelukker ikke at det finnes flere eksempler på vellykkede enkeltprosjekter knyttet til MDIsatsingen og heller ikke at det finnes mindre praksisfellesskap, der medarbeidere og ledere utvikler MDI. Bildet jeg gir her kan derfor virke noe forenklet, da jeg i denne artikkelen peker på noen mer gjennomgående trekk ved implementeringen, ikke på mangfoldet i hendelser og handlinger.

Pragmatismen som teoretisk tilnærming for å forstå implementeringen av MDI i kommuner bidrar til å utfordre translasjonsteoriene på, hvordan organisasjonskonsepter få mening i organisasjoner. Et konsept blir ikke fullt definert gjennom å bli kopiert, adaptert eller omformet for så å «rulles ut» i en ny organisasjon. Det får derimot sin mening gjennom sosiale prosesser av gest-respons, der kopieringen, adapteringen eller omformingen av konseptet kun er den sterke, men initielle, gesten, som organisasjonens deltakere vil re-produsere og re-fortolke gjennom utallige kommunikative situasjoner. I hvilken grad ideer som bryter mot organisasjoners grunnleggende logikker kan implementeres, kommer an på hvilket handlingsrom som kan skapes for handlinger som bryter med de generelle forventingene til riktig handlemåte i organisasjonen. Dette handlingsrommet skapes, utvides og begrenses gjennom deltakernes samhandling, og kan dermed ikke styres av noen alene. 
Implikasjonene disse funnene og diskusjonen kan ha for praksis, vil være at ledere og såkalte «translatører» må være bevisste på at måten ideer og konsepter blir implementert på, også bidrar til å definere og innsnevre konseptets mening. Radikale ideer krever at ledere og medarbeidere vil og kan se mulighetene for alternative rolleforståelser. Dette er ikke kun avhengig av deltakere innen en organisasjon, men også hva som kan være legitimt for en organisasjon som en samfunnsaktør i storsamfunnet.

En metodisk implikasjon fra studien er å forstå translasjonsprosesser som prosessuelle, heller enn å fokusere på de ulike enhetene. Det interessante er ikke nødvendigvis hvilken mening den enkelte idé eller konsept isolert sett får, men i hvilken grad meningen, som utvikles, bidrar til å skape bevegelse i handlingsrom. I stedet for å spørre oss hva konsepter er, bør vi spørre oss hva konsepter gjør. Hva gjør organisasjonskonsepter med organisasjoner, med oppgaver, og hva gjør de med oss som deltakere i samfunnet? Gitt mengden av ressurser og oppmerksomhet som blir lagt ned i å implementere nye konsepter i offentlig sektor, bør vi rette et større kritisk søkelys på hva som skjer i disse prosessene, i hvilken grad de svarer til intensjonene med prosjektene, og hvordan de påvirker offentlig arbeidsliv og brukeropplevelser.

\section{Referanser}

Aasen, T.M., Amundsen, O., Gressgård, L.J., Hansen, K. (2012). Employee-driven innovation in practice - Promoting learning and collaborative innovation by tapping into diverse knowledge sources. In Lifelong learning in Europe 4. https://doi.org/10.1057/9781137014764_3

Crevani, L., \& Endrissat, N. (2016). Mapping the leadership-as-practice terrain. Leadership-as-practice: Theory and application, 2, 21-49. https://doi.org/10.4324/9781315684123-2

Czarniawska, B., and G. Sevón. (1996). "Introduction.” In Translating Organizational Change, edited by B. Czarniawska and G. Sevón, 1-12. Berlin: Walter de Gruyter. https://doi.org/10.1515/9783110879735.1

Czarniawska, B., and B. Joerges. (1996). "Travels of Ideas.” In Translating Organizational Change, edited by B. Czarniawska and G. Sevón, 13-48. Berlin: Walter de Gruyter. https://doi.org/10.1515/9783110879735.13

Gieske, H., George, B., van Meerkerk, I., \& van Buuren, A. (2019). Innovating and optimizing in public organizations: does more become less? Public Management Review, 1-23. https://doi.org/10.1080/14719037.2019.1588356

Griffin, D., \& Stacey, R. D. (Eds.). (2005). Complexity and the experience of leading organizations. Taylor \& Francis.

Hansen, K., Amundsen, O., Aasen, T. M. B., \& Gressgård, L. J. (2017) Management Practices for Promoting Employee-Driven Innovation. I Workplace Innovation (pp. 321-338). Springer, Cham. 
Hjelmar, U. (2019). The institutionalization of public sector innovation. Public Management Review, 1-17. https://doi.org/10.1007/978-3-319-56333-6_19

Holmen, A.K. T. og Ringholm, T. (2019) Innovasjon møter kommune. Oslo. Cappelen Damm akademisk.

Kesting, P., \& Parm Ulhøi, J.: Employee-driven innovation: extending the license to foster innovation. Management decision, 48(1), 65-84 (2010). https://doi.org/10.1108/00251741011014463

Lorino, P. (2018) Pragmatism and Organization Studies. Oxford. Oxford University Press.

Martela, F. (2011, July). Abductive mode of inquiry-A pragmatic alternative for conducting organizational research. In 27th EGOS Colloquium, Gothenburg (pp. 7-9).

Mead, G. H. (1932). The philosophy of the present. New York. Prometheus books.

Mead, G. H. (1934). Mind, self and society (Vol. 111). University of Chicago Press: Chicago.

Nielsen, J. A., Wæraas, A., \& Dahl, K. (2019). When management concepts enter the public sector: a dual-level translation perspective. Public Management Review, 1-21. https://doi.org/10.1080/14719037.2019.1582689

NOU (2016). 3 - Ved et vendepunkt: Fra ressursøkonomi til kunnskapsøkonomi Produktivitetskommisjonens andre rapport

Osborne, S. P., \& Brown, L. (Eds.). (2013). Handbook of innovation in public services. Cheltenham. Edward Elgar Publishing.

Røvik, K. A. (2007). Trender og translasjoner: ideer som former det 21. århundrets organisasjon. Oslo. Universitetsforlaget.

Smith, R. (2017). Work (er)-driven innovation. Journal of Workplace Learning, 29(2), 110-123.

Torfing, J. (2016). Collaborative innovation in the public sector. Georgetown University Press.

Wadel, C. (1999). Kommunikasjon, et mangfoldig samspill. Flekkefjord. SEEK.

${ }^{i}$ https://www.ks.no/fagomrader/innovasjon/innovasjonsledelse/innovasjonsbarometeret-for-kommunalsektor/kommunesektoren-satser-strategisk-pa-innovasjon/ 